\title{
ANALISIS PERSEPSI MASYARAKAT MUSLIM DAN NON MUSLIM TERHADAP KESIAPAN DESTINASI WISATA SYARIAH DI KOTA PEKANBARU DAN PADANG
}

\author{
Putriana, Rimet \\ putriana@uin-suska.ac.id
}

\begin{abstract}
This study aims to determine the perception of Muslim and non-Muslim communities towards the readiness of Islamic tourist destinations in the cities of Pekanbaru and Padang. The problem in this study is how the perception of the people of Pekanbaru and Padang about the readiness of each sharia tourist destination. The population is the community in the city of Pekanbaru and Padang with a total sample of 100 people with the accidental sampling variable method in this study is the perception of maysrakat to the readiness of Islamic tourist destinations. Data analysis techniques using descriptive by getting the readiness of Pekanbaru to become a sharia tourism destination is good, seen by several key indicators, namely: tourist attraction and infrastructure and Pekanbaru has the potential to be developed as a sharia tourist destination and the perception of the people of Padang, West Sumatra City is ready to become a tourist destination. many contain religious elements.
\end{abstract}

Keywords: Sharia Tourism Destinations

\begin{abstract}
ABSTRAK
Penelitian ini betujuan untuk mengetahui persepsi masyarakat muslim dan non muslim terhadap kesiapan destinasi wisata syariah di kota Pekanbaru dan Padang. Permasalahan dalam penelitian ini adalah bagaimana persepsi masyarakat Kota Pekanbaru dan Padang tentang kesiapan masing-masing destinasi wisata syariah. Populasi adalah masyarakat di Kota Pekanbaru dan Padang dengan jumlah sampel sebanyak 100 orang dengan metode Accidental Sampling Variable dalam penelitian ini adalah persepsi maysrakat terhadap kesiapan destinasi wisata syariah. Tekhnik analisa data mengunakan deskriptif dengan mendapatkan hasil kesiapan Pekanbaru menjadi destinasi wisata syariah adalah baik yang dilihat beberapa indikator utama yaitu: daya tarik wisata dan infrastruktur dan Pekanbaru berpotensi untuk dikembangkan sebagai destinasi wisata syariah dan persepsi masyarakat Kota Padang Sumatera Barat telah siap menjadi destinasi wisata yang banyak mengandung unsur religi.
\end{abstract}

\section{Kata Kunci: Destinasi Wisata Syariah}

\section{Pendahuluan}

\section{Latar Belakang}

Seiring dengan perkembangan industri pariwisata, saat ini muncul istilah pariwisata syariah. Pada awalnya konsep syariah umumnya di gunakan pada dunia 
perbankan, namun dunia pariwisata tidak mau ketinggalan. Sebagai negara yang berpenduduk muslim terbanyak di dunia, Indonesia memiliki peluang yang besar untuk menjadi destinasi utama pariwisata syariah dunia. Maka untuk mewujudkan hal tersebut, Kementerian Pariwisata dan Ekonomi Kreatif (Kemenparekraf) bekerjasama dengan Majelis Ulama Indonesia mengadakan Grand Launching Pariwisata Syariah pada tahun 2013.

Kementerian Pariwisata dan Ekonomi Kreatif menetapkan sembilan tujuan wisata yang memiliki potensi untuk dipromosikan sebagai kawasan wisata syariah di Indonesia. Sembilan daerah itu adalah Sumatera Barat, Riau, Lampung, Banten, Jakarta, Jawa Barat, Jawa Timur, Makassar, dan Lombok. Hal ini disebabkan karena kawasan wisata syariah tersebut memiliki latar sosial budaya yang menjunjung tinggi nilai-nilai Islam yang didukung keindahan alamnya (Asdhiana, 2014).

Prinsip yang digunakan dalam wisata syariah adalah untuk memastikan keamanan untuk konsumen dengan menekankan nilai kejujuran, integritas, dan menghormati budaya lokal. Ada lima komponen yang dimasukkan dalam wisata syariah oleh Kemamenparekraf dan MUI yaitu sektor kuliner, fashion moslem, perhotelan dan akomodasi, kosmetik dan spa, serta haji umrah. Jadi wisata syariah saat ini tidak hanya pada peninggalan sejarah Islam, ziarah kubur dan sejenisnya saja. Hal ini merupakan potensi besar yang dimiliki Indonesia yang hasil digarap secara maksimal.

Menurut data Global Moslem Travel Index (GMTI) tahun 2016, Indonesia merupakan salah satu negara anggota OKI (Organisasi Konferensi Islam) yang masuk sepuluh besar daerah tujuan wisata muslim dunia (diurutan ke empat) seperti terlihat pada grafik di bawah ini : 


\section{Grafik 1. Destinasi Wisata Muslim Dunia}

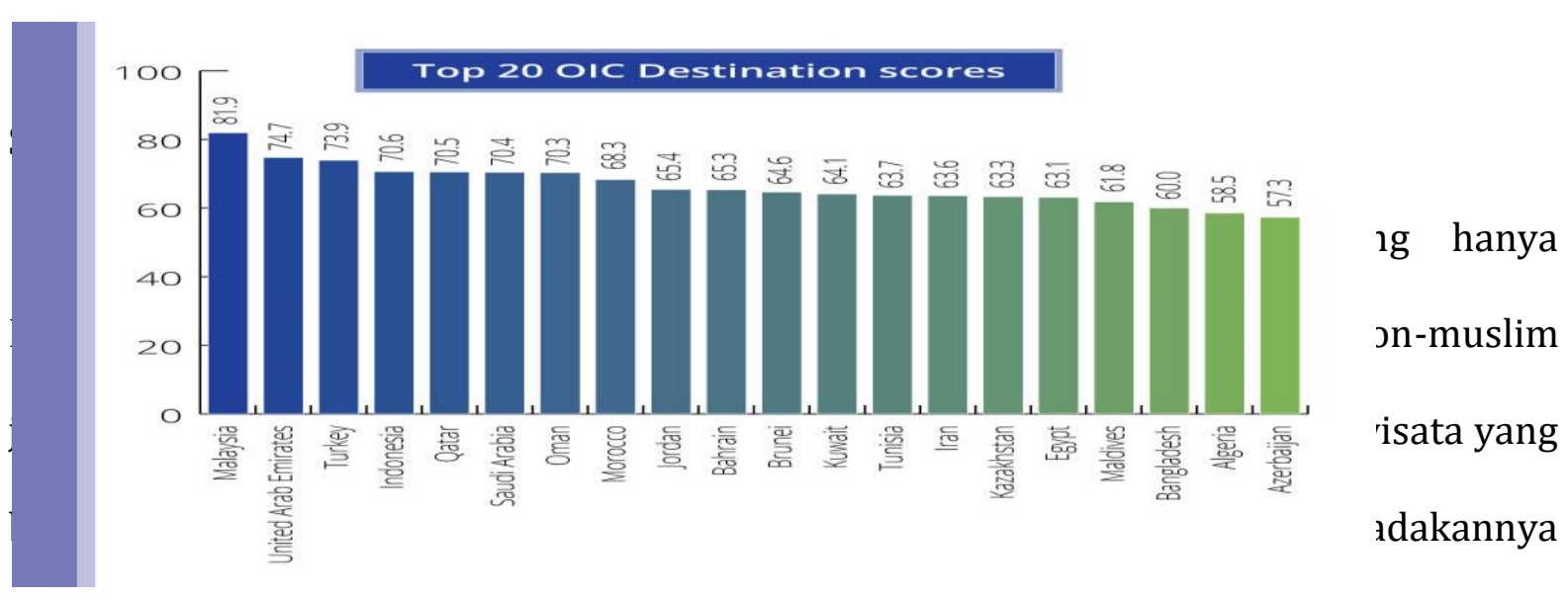

pengembangan wisata syariah adalah untuk menarik wisatawan muslim maupun nonmuslim, dan wisatawan dalam maupun luar negeri serta untuk mendorong tumbuh kembangnya bisnis syariah di lingkungan pariwisata Indonesia. Wisata Syariah memiliki produk dan jasa wisata yang serupa dengan konsep wisata secara konvensional hanya perbedaannya semua pendekatan dan kebijakan yang diterapkan mengacu kepada nilai-nilai Syariah Islam.

Kota Pekanbaru dan Padang sebagai salah satu wilayah yang dikembangkan sebagai destinasi wisata syariah. Hal ini tentunya dinilai dari kesiapan Kota Pekanbaru dan Padang dari sisi infrastruktur maupun kesiapan masyarakat secara keseluruhan juga meliputi dunia usaha serta pemerintah daerah yang memberikan dukungan penuh dalam pengembangannya.

Keberagaman masyarakat Kota Pekanbaru dan Padang juga tentunya menjadi peluang besar sekaligus tantangan dalam mengembangkan pariwisata syariah ini. Namun demikian, masyarakat Indonesia khususnya Kota Pekanbaru dan Padang belum sepenuhnya memahami apa yang disebut wisata syariah, bagaimana implementasinya pada tatanan teknis dan bagaimana kesiapan destinasi wisata syariah yang ada di Pekanbaru dan Padang. 
Berdasarkan uraian di atas, maka penulis akan meneliti persepsi masyarakat terhadap kesiapan destinasi wisata syariah di Kota Pekanbaru dan Padang. Dalam rangka menghadapi persaingan di bidang pariwisata, maka kesiapan dan menerapkan strategi yang tepat untuk wisata syariah sangat penting untuk diketahui dan diterapkan.

\section{Perumusan Masalah}

Adapun permasalahan yang dikemukakan dalam penelitian ini adalah bagaimana persepsi masyarakat Kota Pekanbaru dan Padang tentang kesiapan masing-masing destinasi wisata syariah?

\section{Tujuan Penelitian}

Tujuan penelitian adalah untuk mengetahui persepsi masyarakat Kota Pekanbaru dan Padang tentang kesiapan masing-masing destinasi wisata syariah.

\section{Manfaat Penelitian}

1. Bagi para praktisi, hasil penelitian ini dapat menjadi pertimbangan bagi pengusaha yang bergerak dibidang pariwisata dapat mengembangkan destinasi wisata syariah yang berdaya saing dan mampu menjadikan sektor pariwisata sebagai salah satu andalan dalam memberikan kontribusi terhadap kesejahteraan masyarakat.

2. Bagi konsumen, hasil penelitian ini dapat menjadi masukan dan pengetahuan tentang wisata syariah.

3. Bagi akademisi, hasil penelitian ini dapat menambah khazanah keilmuan khususnya dalam bidang pariwisata.

4. Bagi pemerintah, hasil penelitian ini dapat menjadi acuan untuk merumuskan kebijakan dan regulasi tentang wisata syariah. 


\section{Signifikansi Penelitian}

Penelitian ini memfokuskan pada analisis persepsi masyarakat terhadap kesiapan destinasi wisata syariah di Pekanbaru dan Padang. Kota Pekanbaru dan Padang dipilih sebagai salah satu fokus penelitian karena Kota Pekanbaru terkenal dengan kebudayaan masyarakat Riau yang sangat kental dengan ciri khas melayu, akan menjadi terobosan baru sektor pariwisata. Terletak di posisi yang strategis menjadikan Riau sebagai daerah yang berpotensi untuk mengembangkan sektor pariwisata. Riau bertetangga dengan Provinsi Kepulauan Riau yang memiliki keindahan alam dan kental dengan Budaya Melayu. Riau juga memiliki akses mudah menuju negara jiran seperti Malaysia dan Singapura. Bahkan beberapa maskapai penerbangan, menyediakan rute langsung dengan biaya murahnya seperti Air Asia dan Scoot Airlines. Ini jelas menguntungkan para traveller mancanegara untuk bisa berkunjung ke Indonesia.

Kemudian Sumatera Barat, telah ditetapkan menjadi salah satu destinasi wisata syariah di Indonesia memang menyimpan potensi yang luar biasa dalam mewujudkan konsep kota yang ramah turis muslim. Kultur masyarakat di Sumatera Barat yang menganut budaya Islam memungkinkan daerah ini memiliki dan membangun fasilitas pendukung kepariwisataan yang sesuai dengan syari'ah Islam, seperti hotel, tempat ibadah, kuliner, dan lain-lain. Selain itu, sejak dahulu kala, Sumatera Barat memang sudah terkenal sebagai salah satu destinasi pariwisata di Indonesia yang memiliki tingkat kunjungan yang cukup tinggi. Maka penelitian ini akan mengkaji dari sisi wisatawan sebagai konsumen dalam menilai kesiapan sebagai destinasi wisata syariah.

Potensi pengembangan wisata syariah di Indonesia perlu untuk dikembangkan dan ditingkatkan lagi. Namun potensi besar yang dimiliki Indonesia belum maksimal digarap jika dibanding dengan negara-negara Asia Tenggara lainnya. Beberapa hal yang 
menjadi kendala dalam menerapkan wisata syariah diantaranya aspek sertifikasi produk-produk halal.

Di Indonesia, restoran dan kafe yang menyediakan makanan dan minuman halal masih baru dalam tataran self claim, belum bersertifikat. Jumlah restoran dan hotel yang menjamin makanannya halal masih jarang. Kemudian masih ada beberapa fasilitas yang harus dibenahi untuk memastikan Indonesia siap untuk menyambut wisatawan mancanegara muslim. Toilet hotel dan pusat perbelanjaan mewah banyak mengadaptasi gaya barat. Bahkan terkadang di toilet, hanya tersedia kertas tisu, tanpa air mengalir. Padahal, air mengalir benar-benar penting, terutama untuk bersuci.

Industri pariwisata syariah Indonesia juga harus didukung oleh pemerintah, industri dan strategi pemasaran yang baik, standar dan regulasi yang tepat harus diperkuat oleh tenaga profesional keuangan yang cukup, lembaga pelatihan kepariwisataan syariah yang baik.

\section{Landasan Teori}

\section{Wisata Syariah}

Pariwisata syariah adalah kegiatan yang didukung oleh berbagai fasilitas serta layanan yang disediakan masyarakat, pengusaha, pemerintah, dan pemerintah daerah yang memenuhi ketentuan syariah (Kemenpar, 2012). Menurut Sofyan (2012), definisi wisata syariah lebih luas dari wisata religi yaitu wisata yang didasarkan pada nilai-nilai syariah Islam.

Pariwisata syariah dimanfaatkan oleh banyak orang karena karakteristik produk dan jasanya yang bersifat universal. Produk dan jasa wisata, objek wisata, dan tujuan wisata dalam pariwisata syariah adalah sama dengan produk, jasa, objek dan tujuan pariwisata pada umumnya selama tidak bertentangan dengan nilai-nilai dan etika syariah. 
Konsep syariah yang tidak bertentangan dengan nilai-nilai dan etika syariah berhubungan dengan konsep halal dan haram didalam Islam. Halal diartikan dibenarkan, sedangkan haram diartikan dilarang. Konsep halal dapat dipandang dari dua perspektif yaitu perspektif agama dan perspektif industri. Yang dimaksud dengan perspektif agama, yaitu sebagai hukum makanan apa saja yang boleh dikonsumsi oleh konsumen muslim sesuai keyakinannya. Ini membawa konsekuensi adanya perlindungan konsumen. Sedangkan dari perspektif industri, konsep halal ini dapat diartikan sebagai suatu peluang bisnis bagi produsen pangan. Bagi industri pangan yang target konsumennya sebagian besar muslim, diperlukan adanya jaminan kehalalan produk akan meningkatkan nilainya yang berupa intangible value (Hamzah dan Yudiana, 2015).

Kriteria umum pariwisata syariah ialah (Sofyan, 2012):

1. Memiliki orientasi kepada kemaslahatan umum.

2. Memiliki orientasi pencerahan, penyegaran, dan ketenangan.

3. Menghindari kemusyrikan dan khurafat.

4. Bebas dari maksiat.

5. Menjaga keamanan dan kenyamanan.

6. Menjaga kelestarian lingkungan.

7. Menghormati nilai-nilai sosial budaya dan kearifan lokal.

Adapun perbandingan antara wisata konvensional, wisata religi, dan wisata syariah adalah : 
Tabel 1. Komparasi Wisata Konvensional, Wisata Religi dan Wisata Syariah

\begin{tabular}{|c|c|c|c|c|}
\hline No & Kriteria & Konvesional & Religi & Syariah \\
\hline 1. & Objek & $\begin{array}{l}\text { Alam, Budaya, } \\
\text { Kuliner }\end{array}$ & $\begin{array}{l}\text { Tempat Ibadah, } \\
\text { Peninggalan } \\
\text { Sejarah }\end{array}$ & Semuanya \\
\hline 2. & Tujuan & Menghibur & $\begin{array}{l}\text { Meningkatkan } \\
\text { Spritualitas }\end{array}$ & $\begin{array}{l}\text { Meningkatkan } \\
\text { Spirituaitas } \\
\text { dengan } \\
\text { cara menghibur }\end{array}$ \\
\hline 3. & Target & $\begin{array}{l}\text { Menyentuh } \\
\text { kepuasan dan } \\
\text { kesenangan } \\
\text { yang } \\
\text { berdimensi } \\
\text { nafsu, semata- } \\
\text { mata hanya } \\
\text { untuk hiburan }\end{array}$ & $\begin{array}{l}\text { Aspek spiritual } \\
\text { yang bisa } \\
\text { menenangkan } \\
\text { jiwa }\end{array}$ & $\begin{array}{l}\text { Memenuhi } \\
\text { keinginan dan } \\
\text { kesenangan serta } \\
\text { menumbuhkan } \\
\text { kesadaran } \\
\text { beragama }\end{array}$ \\
\hline 4. & Guide & $\begin{array}{l}\text { Memahami dan } \\
\text { menguasai } \\
\text { informasi } \\
\text { sehingga bisa } \\
\text { menarik } \\
\text { wisatawan } \\
\text { terhadap obyek } \\
\text { wisata }\end{array}$ & $\begin{array}{l}\text { Menguasai } \\
\text { sejarah tokoh } \\
\text { dan lokasi yang } \\
\text { menjadi obyek } \\
\text { wisata }\end{array}$ & $\begin{array}{l}\text { Membuat turis } \\
\text { tertarik pada } \\
\text { obyek sekaligus } \\
\text { membangkitkan } \\
\text { spirit religi } \\
\text { wisatawan. } \\
\text { Mampu } \\
\text { menjelaskan } \\
\text { fungsi dan peran } \\
\text { syariah dalam } \\
\text { bentuk } \\
\text { kebahagiaan dan }\end{array}$ \\
\hline
\end{tabular}




\begin{tabular}{|c|c|c|c|c|}
\hline & & & & $\begin{array}{l}\text { kepuasan batin } \\
\text { dalam kehidupan } \\
\text { manusia. }\end{array}$ \\
\hline 5. & $\begin{array}{l}\text { Fasilitas } \\
\text { Ibadah }\end{array}$ & $\begin{array}{l}\text { Sekedar } \\
\text { pelengkap }\end{array}$ & $\begin{array}{l}\text { Sekedar } \\
\text { pelengkap }\end{array}$ & $\begin{array}{lr}\text { Menjadi } & \text { bagian } \\
\text { yang menyatu } & \\
\text { dengan } & \text { obyek } \\
\text { pariwisata, ritual } \\
\text { ibadah menjadi } \\
\text { bagian } \\
\text { hiburan }\end{array}$ \\
\hline 6. & Kuliner & Umum & Umum & $\begin{array}{l}\text { Spesifik yang } \\
\text { halal }\end{array}$ \\
\hline 7. & $\begin{array}{l}\text { Relasi } \\
\text { dengan } \\
\text { Masyaraka } \\
\text { Dilingkungan } \\
\text { Obyek } \\
\text { Wisata }\end{array}$ & $\begin{array}{l}\text { Komplementar } \\
\text { dan hanya } \\
\text { untuk } \\
\text { keuntungan } \\
\text { materi }\end{array}$ & $\begin{array}{l}\text { Komplementer } \\
\text { dan hanya } \\
\text { untuk } \\
\text { keuntungan } \\
\text { materi }\end{array}$ & $\begin{array}{l}\text { Integrated, } \\
\text { interaksi } \\
\text { berdasar pada } \\
\text { prinsp syariah }\end{array}$ \\
\hline 8. & $\begin{array}{l}\text { Agenda } \\
\text { Perjalanan }\end{array}$ & Setiap Waktu & $\begin{array}{l}\text { Waktu-waktu } \\
\text { tertentu }\end{array}$ & $\begin{array}{l}\text { Memperhatikan } \\
\text { waktu }\end{array}$ \\
\hline
\end{tabular}

Sumber: Ngatawi Al Zaztrow dalam Hamzah dan Yudiana, 2015

\section{Persepsi Konsumen}

Persepsi dapat didefinisikan sebagai suatu proses dimana individu mengorganisasikan dan memaknakan kesan-kesan indera untuk dapat memberikan arti terhadap lingkungannya. Persepsi seseorang terhadap sesuatu dapat berbeda dengan kenyataan yang objektif. Secara etimologi persepsi berasal dari bahasa latin yaitu perceptio yang berarti menerima atau mengambil. Persepsi adalah suatu proses dimana 
berbagai stimuli dipilih, diorganisir, dan diinterpretasi menjadi informasi yang bermakna.

Persepsi adalah sebuah proses individu mengorganisasikan dan menginterpretasikan kesan sensoris untuk memberikan pengertian pada lingkungannya (Robbins, 2015). Dalam Kamus Besar Bahasa Indonesia menerangkan bahwa persepsi adalah tanggapan langsung dari suatu serapan atau proses seorang mengetahui beberapa hal melalui panca inderanya (Depdikbud, 2005).

Persepsi tidak hanya tergantung pada fisik, tetapi juga pada stimuli yang berhubungan dengan lingkungan sekitar dan kondisi individu yang bersangkutan. Persepsi adalah proses kognitif yang memungkinkan kita dapat menafsirkan dan memahami lingkungan sekitar kita. Persepsi juga didefinisikan sebagai proses dimana seseorang memilih, mengorganisasikan, mengartikan masukan informasi untuk menciptakan suatu gambaran yang berarti didunia ini (Sunyoto, 2015).

Menurut Stanton (dalam Setiadi, 2005) Persepsi dapat didefenisikan sebagai makna yang kita pertalikan berdasarkan pengalaman masa lalu, stimuli (rangsanganrangsangan) yang kita terima melalui lima indera. Sedangkan menurut Webster (dalam Setiadi, 2005) persepsi adalah proses bagaimana stimulasi-stimulasi itu diseleksi, diorganisasi, dan diinterpretasikan.

Kotler (2009) menyebutkan bahwa orang dapat membentuk persepsi yang berbeda dari rangsangan yang sama karena tiga proses perseptual: atensi selektif, distorsi selektif, dan retensi selektif.

\section{Atensi selektif (perhatian yang selektif)}

Orang pada umumnya dihadapkan pada jumlah ransangan (stimuli) yang sangat banyak setiap hari dan tidak semua rangsangan ini dapat diterima. Perhatian yang selektif berarti harus dapat menarik perhatian konsumen, dimana pesan 
yang disampaikan akan hilang bagi kebanyak orang yang tidak berada dalam pasar untuk produk tersebut, kecuali untuk pesan yang cukup menonjol atau dominan yang mengelilingi konsumen pasar tersebut.

2. Distorsi selektif (gangguan yang selektif)

Rangsangan (stimuli) yang diperhatikan konsumen pun tidak selalu seperti apa yang dimaksud. Setiap orang berusaha menyesuaikan informasi yang masuk dengan pandangannya. Distorsi selektif menggambarkan kecenderungan orang untuk meramu informasi ke dalam pengertian pribadi. Orang cenderung menafsirkan informasi dengan cara yang lebih mendukung daripada menentang konsepsi-konsepsi yang telah dimilikinya.

3. Retensi selektif (mengingat kembali yang selektif)

Orang cenderung melupakan apa yang mereka pelajari dan menahan informasi yang mendukung sikap dan kepercayaan mereka. Mengingat yang selektif berarti mereka akan mengingat apa yang dikatakan sebagai keunggulan suatu produk dan melupakan apa yang dikatakan pesaing. Konsumen akan mengingatnya pada saat ia mengingat tentang pemilihan sebuah produk.

\section{Faktor-faktor yang Mempengaruhi Persepsi}

Menurut Walgito (2004) faktor-faktor lain yang berperan terhadap adanya persepsi yaitu:

1. Obyek yang dipersepsikan, obyek akan menimbulkan stimulus yang mengenai alat indera atau reseptor. Stimulus dapat datang dari luar individu yang mempersepsikan, tetapi juga dapat datang dari dalam individu.

2. Alat indera, syaraf dan pusat susunan syaraf merupakan alat untuk menerima rangsangan yang diteruskan oleh syaraf sensorik untuk diterima dan diolah dipusat susunan syaraf yaitu otak sebagai pusat kesadaran. 
3. Adanya perhatian terhadap obyek merupakan langkah pertama dalam mengadakan persepsi, karena tanpa ada perhatian maka tidak akan ada persepsi. Faktor-faktor yang mempengaruhi persepsi menurut Stephen P. Robbins (2015) ketika anda melihat sebuah target, interpretasi anda tentang apa yang anda lihat dipengaruhi oleh karakteristik-karateristik pribadi anda, kepribadian, motif, minat, pengalaman masa lampau, dan ekspektasi. Karakteristik dari target juga memengaruhi apa yang kita nilai.

Menurut Sungadji dan Sopiah (2013) terdapat dua faktor yang mempengaruhi berinteraksi dalam penentuan persepsi yaitu :

1. Karakteristik stimulus yang mempengaruhi persepsi

Karakteristik-karakteristik tersebut dibagi menjadi dua kelompok, yaitu elemen indrawi (sensory element), seperti bau, rasa, suara penglihatan, dan pendengaran, dan elemen struktural (structural element) seperti ukuran, bentuk, dan posisi.

2. Karakteristik konsumen yang mempengaruhi persepsi

Beberapa karakteristik konsumen yang memengaruhi persepsi adalah:

a. Perbedaan stimulus

b. Tingkat ambang atas (threshild level)

c. Persepsi bawah sadar (subliminal perception)

d. Tingkat adaptasi

e. Generalisasi stimulus proses

\section{Penelitian Terdahulu}

Kajian penelitian terdahulu diperlukan sebagai bahan referensi dan penuntun dalam penentuan metode dalam menganalisis data penelitian. Penelitian ini mengkaji persepsi masyarakat Kota Pekanbaru dan Padang tentang kesiapan masing-masing destinasi wisata syariah. 
Tabel 2. Penelitian Terdahulu

\begin{tabular}{|c|c|c|c|c|}
\hline No & $\begin{array}{l}\text { Penulis / } \\
\text { Tahun }\end{array}$ & $\begin{array}{c}\text { Judul } \\
\text { Penelitian }\end{array}$ & Variabel & Hasil Penelitian \\
\hline 1 & $\begin{array}{l}\text { I Made } \\
\text { Darsana } \\
(2015)\end{array}$ & $\begin{array}{l}\text { Persepsi } \\
\text { Masyarakat } \\
\text { Bali Terhadap } \\
\text { Sistem } \\
\text { Kastadi Desa } \\
\text { Buyut Baru } \\
\text { Kecamatan } \\
\text { Seputih } \\
\text { Raman } \\
\text { Kabupaten } \\
\text { Lampung } \\
\text { Tengah Tahun } \\
\text { 2015. }\end{array}$ & - Persepsi & $\begin{array}{lrr}\text { Persepsi } & \text { masyarakat } \\
\text { Bali terhadap } & \text { sistem } \\
\text { kasta di } & \text { Desa } & \text { Buyut } \\
\text { Baru } & \text { Kecamatan } \\
\text { Seputih } & \text { Raman } \\
\text { Kabupaten } & \text { Lampung } \\
\text { Tengah } & \text { dengan } \\
\text { jumlah } & \text { responden } \\
\text { sebanyak } 18 & \text { KK dan } 20 \\
\text { item soal, } & \text { didapatkan } \\
\text { sebanyak } 9 & \text { responden } \\
\text { atau } 50 \% \text { masuk dalam } \\
\text { kategori tidak setuju }\end{array}$ \\
\hline 2 & $\begin{array}{l}\text { Hidayatullah } \\
\text { Surya } \\
\text { Dirgabrat } \\
(2014)\end{array}$ & $\begin{array}{l}\text { Implementasi } \\
\text { MarketingMix } \\
\text { dan } \\
\text { Pengaruhnya } \\
\text { Terhadap } \\
\text { Minat } \\
\text { Berkunjung } \\
\text { ke Taman } \\
\text { Wisata } \\
\text { Lembah Hijau }\end{array}$ & $\begin{array}{l}\text { - Product } \\
\text { - Price } \\
\text { - Promotion } \\
\text { - Process } \\
\text { - People } \\
\text { - Pyshical } \\
\text { evidence }\end{array}$ & 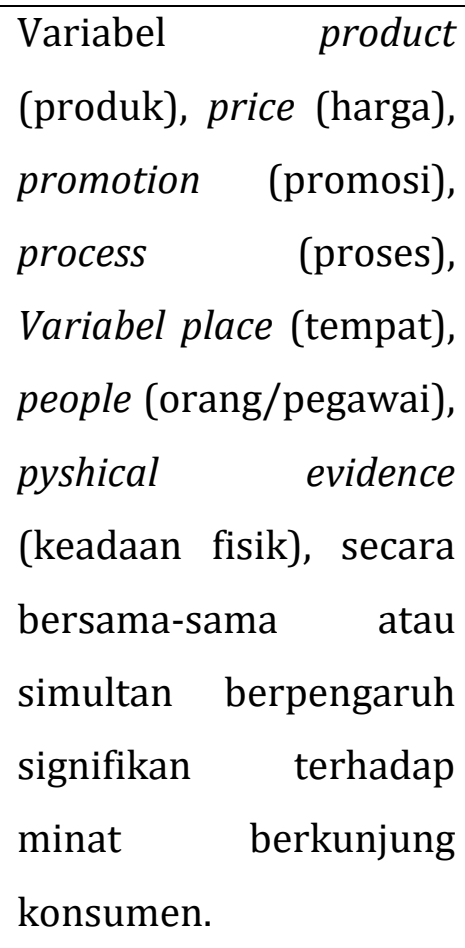 \\
\hline 3 & $\begin{array}{l}\text { Mevlut } \\
\text { Akyol dan }\end{array}$ & $\begin{array}{l}\text { Internet and } \\
\text { Halal Tourism }\end{array}$ & $\begin{array}{l}\text { - Marketing } \\
\text { halal }\end{array}$ & $\begin{array}{l}\text { Pelaku marketing halal } \\
\text { harus }\end{array}$ \\
\hline
\end{tabular}




\begin{tabular}{|c|c|c|c|c|}
\hline & $\begin{array}{l}\text { Ozgur Kilinc } \\
\text { (2014) }\end{array}$ & Marketing & $\begin{array}{l}\text { - Wisata } \\
\text { halal } \\
\text { - Hotel halal }\end{array}$ & $\begin{array}{l}\text { mempertimbangkan } \\
\text { harapan hotel halal baik } \\
\text { untuk wisatawan } \\
\text { Muslim dan non- } \\
\text { Muslim. Muslim mencari } \\
\text { liburan yang koheren } \\
\text { dengan Islam dan } \\
\text { harapan non-Muslim } \\
\text { juga mendapatkan } \\
\text { keamanan dan } \\
\text { kebersihan. Hal tersebut } \\
\text { harus diperhitungkan } \\
\text { oleh pelaku marketing } \\
\text { halal. }\end{array}$ \\
\hline 4. & $\begin{array}{l}\text { M. Maulana } \\
\text { Hamzah } \\
\text { dan Yudi } \\
\text { Yudiana } \\
\text { (2015) }\end{array}$ & $\begin{array}{l}\text { Analisis } \\
\text { Komparatif } \\
\text { Potensi } \\
\text { Industri Halal } \\
\text { dalam } \\
\text { Wisata } \\
\text { Syariah } \\
\text { dengan } \\
\text { Konvensional }\end{array}$ & $\begin{array}{l}\text { - Wisata } \\
\text { syariah } \\
\text { - Wisata } \\
\text { konvensio } \\
\text { nal }\end{array}$ & $\begin{array}{l}\text { Perlu mengintegrasikan } \\
\text { antara wisata syariah } \\
\text { dan konvensional untuk } \\
\text { difokuskan pada } \\
\text { industri halal. Dalam } \\
\text { perkembangannya } \\
\text { wisata konvensional } \\
\text { lebih dulu berkembang } \\
\text { dibandingkan wacana } \\
\text { wisata syariah }\end{array}$ \\
\hline
\end{tabular}

Sumber : Data Olahan (2018) 


\section{Kerangka Konseptual}

Kerangka konseptual yang dikembangkan dalam penelitian ini adalah sebagai berikut :

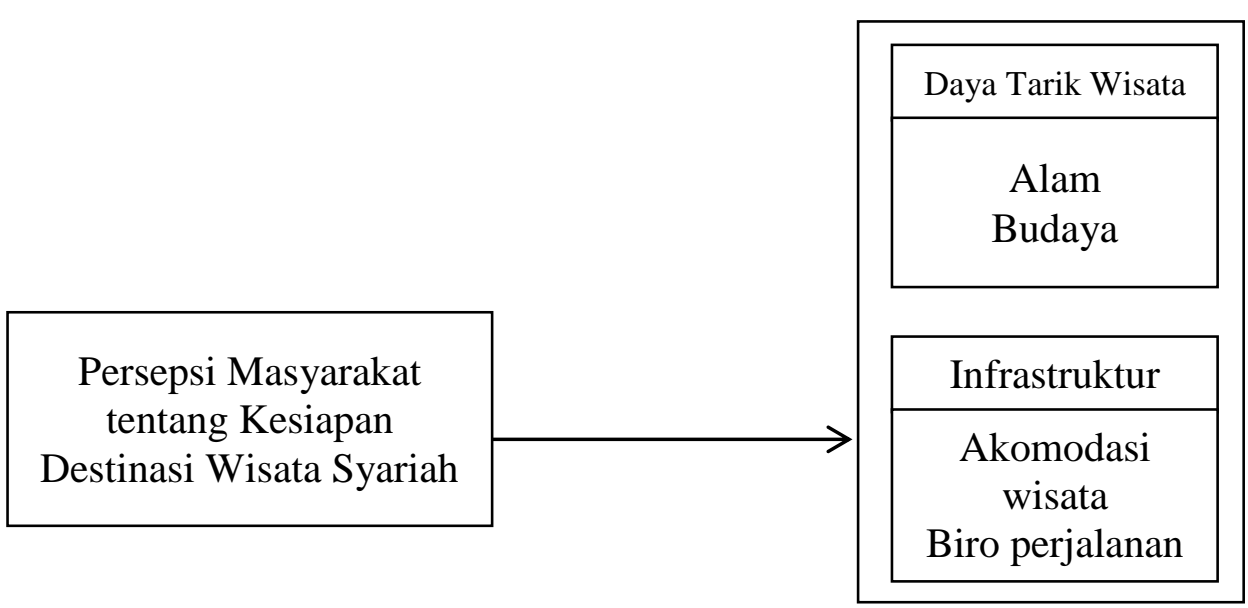

\section{Gambar 1. Kerangka Konseptual}

\section{Hipotesis}

Hipotesis dalam penelitian ini adalah diduga persepsi masyarakat Kota Pekanbaru dan Padang tentang kesiapan masing-masing destinasi wisata syariah menyatakan baik dan siap.

\section{Metode Penelitian}

\section{Lokasi Penelitian}

Lokasi penelitian adalah di Kota Pekanbaru dan Padang.

\section{Objek Penelitian}

Objek penelitian adalah masyarakat muslim dan non-muslim yang ada di Kota Pekanbaru dan Padang.

\section{Teknik Pengumpulan Data}

Adapun teknik pengumpulan data yang digunakan dalam penelitian ini adalah:

1. Observasi 
Digunakan untuk mengamati gejala-gejala terwujud dalam kehidupan sehari-hari dari masyarakat yang diteliti. Metode ini memberi gejala-gejala (tindakantindakan, benda, peristiwa dan sebagainya) dan kaitan hubungan antara satu gejala dengan gejala yang lainnya yang bermakna bagi kehidupan masyarakat yang diteliti.

2. Wawancara

Yaitu teknik yang dapat digunakan untuk memperoleh data atau informasi secara langsung pada informan. Teknik ini bertujuan untuk mengumpulkan keterangan tentang kehidupan manusia dalam masyarakat serta pendirian-pendirian mereka dalam hal-hal tertentu.

3. Kuesioner

adalah teknik pengumpulan data dengan mengajukan sejumlah pertanyaan secara tertulis yang diberikan kepada responden dengan maksud untuk memperoleh data yang akurat dan valid.

\section{Populasi dan Sampel}

Populasi adalah jumlah keseluruhan dari unit analisa yang ciri-cirinya akan diduga (Singarimbun dan Effendi, 1984). Populasi adalah para masyarakat di Kota Pekanbaru dan Padang. Dalam hal ini jumlah populasi masyarakat Pekanbaru adalah 1.064.566 jiwa (BPS Pekanbaru, 2017) dan populasi masyarakat Padang adalah 914.968 jiwa (BPS Padang, 2017).

Dalam menentukan sampel untuk Pekanbaru dan Padang, penulis menggunakan rumus dari Slovin (Umar, 2008) sebagai berikut:

$$
\mathrm{n}=\frac{N}{1+N e^{2}}
$$

Dimana :

$\mathrm{n}=$ Ukuran sampel 
$\mathrm{N}=$ Ukuran populasi

$\mathrm{e}=$ Taraf kesalahan $10 \%$

Dengan rumus Slovin diatas untuk populasi Pekanbaru yang akan dijadikan jumlah sampel yang akan dijadikan objek penelitian dengan toleransi tingkat kesalahan $10 \%$ adalah :

$$
\begin{aligned}
& \mathrm{n}=\frac{\mathrm{N}}{1+\mathrm{Ne}^{2}} \\
& \mathrm{n}=\frac{1.064 .566}{1+1.064 .566(10 \%)^{2}} \\
& \mathrm{n}=99,9
\end{aligned}
$$

Maka jumlah sampel untuk Pekanbaru adalah sebanyak 100 orang responden. Metode yang digunakan untuk menentukan sampel adalah metode accidental sampling yaitu memilih sampel dari orang atau unit yang paling mudah dijumpai atau diakses sehingga pengumpulan datanya mudah dan terpenuhinya jumlah yang telah ditetapkan.

Kemudian dengan menggunakan rumus Slovin juga ditentukan sampel untuk Padang yang akan dijadikan objek penelitian dengan toleransi tingkat kesalahan 10\% adalah :

$$
\begin{aligned}
& \mathrm{n}=\frac{\mathrm{N}}{1+\mathrm{Ne}^{2}} \\
& \mathrm{n}=\frac{914.968}{1+914.968(10 \%)^{2}} \\
& \mathrm{n}=99
\end{aligned}
$$

Maka jumlah sampel untuk Padang adalah sebanyak 100 orang responden. Metode yang digunakan untuk menentukan sampel adalah metode accidental sampling yaitu memilih sampel dari orang atau unit yang paling mudah dijumpai atau diakses sehingga pengumpulan datanya mudah dan terpenuhinya jumlah yang telah ditetapkan.

\section{Jenis dan Sumber Data}

1. Data primer 
Adalah data yang diperoleh melalui penelitian langsung terhadap objek yang diteliti.

\section{Data sekunder}

Adalah data yang diperoleh dari berbagai sumber antara lain dari dokumentasi / tulisan dan dari informasi pihak-pihak yang berkaitan dengan penelitian ini.

\section{Definisi Operasional Variabel}

Sugiyono (1997) definisi variabel adalah merupakan gejala yang menjadi fokus penelitian untuk dinikmati. Sedangkan dalam bahasa Singarimbun dan Sofyan (Umar, 1982) variabel adalah sesuatu yang memiliki variasi nilai sebagai operasionalisasi dari konsep sehingga dapat di teliti secara empiris. Bertolak dari kedua argumen diatas maka variabel merupakan dimensi konsep yang memiliki variasi nilai dan menjadi pokok yang berperan dalam objek yang diteliti. Variabel dalam penelitian adalah persepi masyarakat terhadap kesiapan destinasi wisata syariah, dengan sub variabelnya:

1. Daya tarik wisata

2. Infrastruktur wisata syariah

Tabel 3.1 di bawah ini akan dikemukakan variabel, sub-variabel dan indikator penelitian: 
Tabel 3.1. Variabel dan Indikator Penelitian

\begin{tabular}{|c|c|c|}
\hline Variabel & $\begin{array}{c}\text { Sub } \\
\text { Variabel }\end{array}$ & Indikator \\
\hline \multirow{16}{*}{$\begin{array}{l}\text { Persepsi } \\
\text { masyarakat } \\
\text { terhadap } \\
\text { kesiapan } \\
\text { destinasi } \\
\text { wisata } \\
\text { syariah }\end{array}$} & \multirow[t]{5}{*}{$\begin{array}{l}\text { Daya tarik } \\
\text { wisata }\end{array}$} & $\begin{array}{l}\text { Daya tarik wisata yang meliputi wisata alam, } \\
\text { wisata budaya dan wisata buatan }\end{array}$ \\
\hline & & Memiliki memiliki daya tarik wisata belanja \\
\hline & & Memiliki daya tarik wisata kuliner \\
\hline & & $\begin{array}{llrr}\text { Pertunjukan } & \text { seni } & \text { budaya } & \text { yang } \\
\text { diselenggarakan } & \text { tidak } & \text { bertentangan dengan } \\
\text { kaidah syariah } & & & \end{array}$ \\
\hline & & $\begin{array}{l}\text { Tersedia tempat ibadah layak, suci dan } \\
\text { dilengkapi sarana bersuci yang memadai }\end{array}$ \\
\hline & \multirow{11}{*}{$\begin{array}{l}\text { Infrastruktur } \\
\text { wisata } \\
\text { syariah } \\
\text { (akomodasi } \\
\text { wisata } \\
\text { syariah dan } \\
\text { biro } \\
\text { perjalanan } \\
\text { wisata) }\end{array}$} & Akomodasi Wisata Syariah : \\
\hline & & $\begin{array}{l}\text { Hotel yang ditempati menyediakan makanan } \\
\text { halal }\end{array}$ \\
\hline & & $\begin{array}{l}\text { Hotel yang ditempati menyediakan minuman } \\
\text { halal }\end{array}$ \\
\hline & & $\begin{array}{l}\text { Fasilitas hotel nyaman dan kondusif untuk } \\
\text { keluarga }\end{array}$ \\
\hline & & $\begin{array}{l}\text { Suasana hotel yang ditempati aman, nyaman } \\
\text { dan kondusif untuk keluarga }\end{array}$ \\
\hline & & $\begin{array}{l}\text { Kebersihan sanitasi dan lingkungan hotel } \\
\text { yang ditempati terjaga }\end{array}$ \\
\hline & & Biro Perjalanan Wisata \\
\hline & & $\begin{array}{l}\text { Biro perjalanan menyediakan } \\
\text { perjalanan/wisata yang sesuai } \\
\text { dengan } \\
\text { prinsip-prinsip syariah atau Islam }\end{array}$ \\
\hline & & $\begin{array}{l}\text { Pemandu wisata berpenampilan sopan dan } \\
\text { menarik sesuai dengan nilai etika Islam }\end{array}$ \\
\hline & & $\begin{array}{l}\text { Adanya kemudahan akses informasi wisata } \\
\text { syariah/halal }\end{array}$ \\
\hline & & Biaya transportasi sesuai standar \\
\hline
\end{tabular}




\section{Teknik Analisis Data}

Ada dua pengukuran variabel, yaitu daya tarik wisata dan infrastruktur. Dari setiap variabel ditentukan sub variabel dan indikator untuk masing-masing sub variabel. Penilaian terhadap indikator menggunakan interval dengan Sangat Baik (SB), Baik (B), Netral (N), Tidak Baik (TB), dan Sangat Tidak Baik (STB).

Analisis yang digunakan adalah deskriptif dengan alasan untuk memberikan gambaran (deskripsi) mengenai suatu data agar data yang tersaji menjadi mudah dipahami sehingga dapat menjadi informasi bagi setiap orang yang membacanya.

\section{Hasil Penelitian dan Pembahasan}

\section{Persepsi Masyarakat Terhadap Kesiapan Destinasi Wisata Syariah di Pekanbaru}

Diberbagai kota besar di Indonesia sudah mulai populer dengan mengembangkan wisata syariah. Konsep wisata syariah ini cocok untuk dikembangkan di Pekanbaru, yang memiliki kekuatan budaya Melayu. Berdasarkan hasil penelitian maka persepsi masyarakat terhadap kesiapan destinasi wisata syariah di Pekanbaru dilihat dari dua variabel, yaitu:

1. Daya tarik wisata

2. Infrastruktur wisata syariah di Pekanbaru

Berikut ini adalah hasil tanggapan responden mengenai indikator kesiapan destinasi wisata syariah di Pekanbaru.

\section{Daya Tarik Wisata}

Terdapat lima pertanyaan yang berhubungan dengan daya tarik wisata Pekanbaru sebagai destinasi wisata syariah berdasarkan persepsi masyarakat, yaitu daya tarik wisata yang meliputi wisata alam, wisata budaya dan wisata buatan; Pekanbaru memiliki memiliki daya tarik wisata belanja; Pekanbaru memiliki daya tarik wisata kuliner; pertunjukan seni budaya yang diselenggarakan tidak bertentangan 
dengan kaidah syariah; tersedia tempat ibadah layak, suci dan dilengkapi sarana bersuci yang memadai.

Berdasarkan scoring persepsi responden mengenai daya tarik wisata alam, wisata budaya dan wisata buatan Pekanbaru masih belum maksimal disebabkan karena menurut persepsi responden wisata alam Pekanbaru masih dirasakan kurang sehingga perlu bagi pemerintah daerah untuk dapat mengembangkan destinasi wisata alam Pekanbaru sebagai salah satu daya tarik wisata di Pekanbaru.

Kemudian scoring persepsi responden mengenai Pekanbaru memiliki daya tarik wisata belanja adalah sangat baik disebabkan karena menurut persepsi responden destinasi atau tempat wisata belanja di Pekanbaru sudah dirasakan memadai bagi masyarakat.

Selanjutnya scoring persepsi responden mengenai Pekanbaru memiliki daya tarik wisata kuliner dengan menggunakan skala Likert menghasilkan nilai 455. Jadi untuk pertanyaan ini berada pada kategori sangat baik.

Persepsi responden mengenai Pekanbaru memiliki daya tarik wisata kuliner adalah sangat baik disebabkan karena menurut persepsi responden Pekanbaru memiliki variasi dalam hal kuliner terutama makanan khas Melayu. Hal ini sudah baik menurut persepsi responden.

Scoring persepsi responden mengenai pertunjukan seni budaya yang diselenggarakan tidak bertentangan dengan kaidah syariah adalah sangat baik disebabkan karena menurut persepsi responden Pekanbaru adalah negeri Melayu yang jiwa dan semangat keagamaannya sangat tinggi sehingga hal ini juga tercermin dalam seni pertunjukkan budaya yang dimiliki Pekanbaru. Hal ini sudah sudah sesuai dengan prinsip wisata syariah yang diinginkan dan ini adalah baik menurut persepsi responden. 
Persepsi responden mengenai ketersediaan tempat ibadah layak, suci dan dilengkapi sarana bersuci yang memadai adalah sangat baik disebabkan karena menurut persepsi responden Pekanbaru tempat-tempat ibadah di Pekanbaru sangat memadai dari segi jumlah, akses dan sarananya. Hal ini juga sudah sudah sesuai dengan prinsip wisata syariah yang diinginkan masyarakat dan ini adalah baik menurut persepsi responden.

\section{Infrastruktur Wisata Syariah}

Infrastruktur wisata syariah dibagi menjadi dua indikator, yaitu akomodasi wisata syariah dan biro perjalanan wisata.

Terdapat lima pertanyaan yang berhubungan dengan akomodasi wisata syariah di Pekanbaru berdasarkan persepsi masyarakat, yaitu hotel yang ditempati menyediakan makanan halal; hotel yang ditempati menyediakan minuman halal; fasilitas hotel nyaman dan kondusif untuk keluarga; suasana hotel yang ditempati aman, nyaman dan kondusif untuk keluarga; kebersihan sanitasi dan lingkungan hotel yang ditempati terjaga.

Scoring persepsi responden mengenai jawaban pada pertanyaan hotel yang ditempati menyediakan makanan halal dengan menggunakan skala Likert menghasilkan nilai 482. Jadi untuk pertanyaan pertama berada pada kategori sangat baik.

Selanjutnya persepsi responden mengenai fasilitas hotel nyaman dan kondusif untuk keluarga dengan menggunakan skala Likert menghasilkan nilai 479. Jadi untuk pertanyaan ini berada pada kategori sangat baik.

Mengenai suasana hotel yang ditempati aman, nyaman dan kondusif untuk keluarga dengan menggunakan skala Likert menghasilkan nilai 478. Jadi untuk pertanyaan ini berada pada kategori sangat baik. 
Persepsi responden mengenai kebersihan sanitasi dan lingkungan hotel yang ditempati terjaga dengan menggunakan skala Likert menghasilkan nilai 483. Jadi untuk pertanyaan ini berada pada kategori sangat baik.

Selanjutnya terdapat empat pertanyaan yang berhubungan dengan biro perjalanan wisata di Pekanbaru berdasarkan persepsi masyarakat, yaitu biro perjalanan menyediakan paket perjalanan/wisata yang sesuai dengan prinsip-prinsip syariah atau Islam, pemandu wisata berpenampilan sopan dan menarik sesuai dengan nilai etika Islam, adanya kemudahan akses informasi wisata syariah/halal, biaya transportasi sesuai standar.

Scoring persepsi responden mengenai jawaban pada pertanyaan biro perjalanan menyediakan paket perjalanan/wisata yang sesuai dengan prinsip-prinsip syariah atau Islamdengan menggunakan skala Likert menghasilkan nilai 440. Jadi untuk pertanyaan pertama berada pada kategori sangat baik.

Persepsi responden mengenai jawaban pada pertanyaan pemandu wisata berpenampilan sopan dan menarik sesuai dengan nilai etika Islam dengan menggunakan skala Likert menghasilkan nilai 425. Jadi untuk pertanyaan ini berada pada kategori sangat baik.

Mengenai persepsi responden mengenai adanya kemudahan akses informasi wisata syariah/halaldengan menggunakan skala Likert menghasilkan nilai 440. Jadi untuk pertanyaan ini berada pada kategori sangat baik.

Scoring persepsi responden mengenai biaya transportasi sesuai standar dengan menggunakan skala Likert menghasilkan nilai 487. Jadi untuk pertanyaan ini berada pada kategori sangat baik.

Jadi berdasarkan hasil penelitian dapat disimpulkan bahwa kesiapan Pekanbaru 
menjadi destinasi wisata syariah adalah baik yang dilihat beberapa indikator utama yaitu: daya tarik wisata dan infastruktur. Dari kedua indikator tersebut dapat pula dikatakan bahwa Pekanbaru mempunyai potensi untuk dikembangkan sebagai destinasi wisata syariah. Di Pekanbaru terdapat Hotel berbintang yang mengusung konsep syariah di Kota Pekanbaru. Beberapa hotel berbintang yang menerapkan prinsip syariah seperti Hotel Zaira, D'Lira, Stefani serta Hotel Syariah UIN Suska. Ada juga hotel yang menamakan diri hotel halal seperti Hotel Pessona. Kemudian ada Hotel Syariah Sri Indrayani yang berbintang tiga yang juga sudah menerapkan konsep syariah

Potensi daya tarik tersebut telah didukung dengan ketersedian faslitas yang muslim friendly seperti tempat ibadah di masing-masing daya tarik wisata. Wisatawan muslim tidak terlalu sulit untuk menemukan tempat ibadah (sholat) selama melakukan aktivitas wisata di Pekanbaru.

\section{Persepsi Masyarakat Terhadap Kesiapan Destinasi Wisata Syariah di Padang}

Berdasarkan hasil penelitian maka persepsi masyarakat terhadap kesiapan destinasi wisata syariah di Padang juga dilihat dari dua variabel, yaitu :

\section{Daya tarik wisata}

2. Infrastruktur wisata syariah di Padang

Berikut ini adalah hasil tanggapan responden mengenai indikator kesiapan destinasi wisata syariah di Padang.

\section{Daya Tarik Wisata}

Terdapat lima pertanyaan yang berhubungan dengan daya tarik wisata Padang sebagai destinasi wisata syariah berdasarkan persepsi masyarakat, yaitu daya tarik wisata yang meliputi wisata alam, wisata budaya dan wisata buatan; Padang memiliki memiliki daya tarik wisata belanja; Padang memiliki daya tarik wisata kuliner; pertunjukan seni budaya yang diselenggarakan tidak bertentangan dengan kaidah 
syariah; tersedia tempat ibadah layak, suci dan dilengkapi sarana bersuci yang memadai.

Persepsi responden mengenai jawaban pada pertanyaan daya tarik wisata alam, wisata budaya dan wisata buatan Padang dengan menggunakan skala Likert menghasilkan nilai 478. Jadi untuk pertanyaan pertama berada pada kategori sangat baik.

Adapun persepsi responden mengenai daya tarik wisata alam, wisata budaya dan wisata buatan Padang sangat baik disebabkan karena menurut persepsi responden terutama dalam hal wisata alam Padang memiliki banyak pilihan destinasi yang bisa dikunjungi wisatawan sehingga wisata alam menjadi salah satu daya tarik wisata di Padang.

Kemudian persepsi responden mengenai jawaban pada pertanyaan Padang memiliki daya tarik wisata belanja dengan menggunakan skala Likert menghasilkan nilai 444. Jadi untuk pertanyaan ini berada pada kategori sangat baik.

Selanjutnya persepsi responden mengenai Padang memiliki daya tarik wisata belanja adalah sangat baik disebabkan karena menurut persepsi responden Padang memiliki banyak menawarkan cenderamata atau barang-barang khas Minang yang menjadi menarik minat belanja para wisatawan.

Scoring persepsi responden mengenai Padang memiliki daya tarik wisata kuliner dengan menggunakan skala Likert menghasilkan nilai 492. Jadi untuk pertanyaan ini berada pada kategori sangat baik.

Demikian juga dengan persepsi responden mengenai Padang memiliki daya tarik wisata kuliner adalah sangat baik disebabkan karena menurut persepsi responden Padang memang memiliki kelebihan dalam hal kuliner dimana banyak makanan khas 
Minang yang bisa dipilih oleh wisatawan sehingga persepsi responden tentang wisata kuliner Padang sangat baik.

Scoring persepsi responden mengenai pertunjukan seni budaya yang diselenggarakan tidak bertentangan dengan kaidah syariah dengan menggunakan skala Likert menghasilkan nilai 479. Jadi untuk pertanyaan ini berada pada kategori sangat baik.

Persepsi responden mengenai pertunjukan seni budaya yang diselenggarakan tidak bertentangan dengan kaidah syariah adalah sangat baik disebabkan karena menurut persepsi responden Padang adalah daerah yang nilai-nilai keagamaan sangat dijunjung tinggi sehingga tercermin dalam seni pertunjukkan budaya yang dimiliki Padang. Hal ini sudah sesuai dengan prinsip wisata syariah yang diinginkan dan ini adalah baik menurut persepsi responden.

Scoring persepsi responden mengenai ketersediaan tempat ibadah layak, suci dan dilengkapi sarana bersuci yang memadai dengan menggunakan skala Likert menghasilkan nilai 424. Jadi untuk pertanyaan ini berada pada kategori sangat baik.

Jadi scoring persepsi responden mengenai ketersediaan tempat ibadah layak, suci dan dilengkapi sarana bersuci yang memadai adalah sangat baik disebabkan karena menurut persepsi responden mengenai tempat-tempat ibadah di Padang sangat memadai dari segi jumlah, akses dan sarananya. Hal ini juga sudah sudah sesuai dengan prinsip wisata syariah yang diinginkan masyarakat dan ini adalah baik menurut persepsi responden.

\section{Infrastruktur Wisata Syariah}

Infrastruktur wisata syariah di Padang akan dijelaskan dalam dua indikator yaitu akomodasi wisata syariah dan biro perjalanan wisata syariah. Terdapat lima pertanyaan yang berhubungan dengan akomodasi wisata syariah di Padang berdasarkan persepsi 
masyarakat, yaitu hotel yang ditempati menyediakan makanan halal; hotel yang ditempati menyediakan minuman halal; fasilitas hotel nyaman dan kondusif untuk keluarga; suasana hotel yang ditempati aman, nyaman dan kondusif untuk keluarga; kebersihan sanitasi dan lingkungan hotel yang ditempati terjaga.

Persepsi responden mengenai jawaban pada pertanyaan hotel yang ditempati menyediakan makanan halal dengan menggunakan skala Likert menghasilkan nilai 489. Jadi untuk pertanyaan pertama berada pada kategori sangat baik.

Scoring persepsi responden mengenai jawaban pada pertanyaan hotel yang ditempati menyediakan minuman halal dengan menggunakan skala Likert menghasilkan nilai 487. Jadi untuk pertanyaan ini berada pada kategori sangat baik.

Selanjutnya persepsi responden mengenai fasilitas hotel nyaman dan kondusif untuk keluarga dengan menggunakan skala Likert menghasilkan nilai 485. Jadi untuk pertanyaan ini berada pada kategori sangat baik.

Kemudian persepsi responden mengenai suasana hotel yang ditempati aman, nyaman dan kondusif untuk keluarga dengan menggunakan skala Likert menghasilkan nilai 481. Jadi untuk pertanyaan ini berada pada kategori sangat baik.

Scoring persepsi responden mengenai kebersihan sanitasi dan lingkungan hotel yang ditempati terjaga dengan menggunakan skala Likert menghasilkan nilai 486. Jadi untuk pertanyaan ini berada pada kategori sangat baik.

Selanjutnya terdapat empat pertanyaan yang berhubungan dengan biro perjalanan wisata di Padang berdasarkan persepsi masyarakat, yaitu biro perjalanan menyediakan paket perjalanan/wisata yang sesuai dengan prinsip-prinsip syariah atau Islam, pemandu wisata berpenampilan sopan dan menarik sesuai dengan nilai etika Islam, adanya kemudahan akses informasi wisata syariah/halal, biaya transportasi sesuai standar. 
Scoring persepsi responden mengenai jawaban pada pertanyaan biro perjalanan menyediakan paket perjalanan/wisata yang sesuai dengan prinsip-prinsip syariah atau Islam dengan menggunakan skala Likert menghasilkan nilai 466. Jadi untuk pertanyaan pertama berada pada kategori sangat baik.

Persepsi responden mengenai jawaban pada pertanyaan biaya transportasi sesuai standar dengan menggunakan skala Likert menghasilkan nilai 438. Jadi untuk pertanyaan ini berada pada kategori sangat baik.

Scoring persepsi responden mengenai kemudahan akses informasi wisata syariah/halal dengan menggunakan skala Likert menghasilkan nilai 462. Jadi untuk pertanyaan ini berada pada kategori sangat baik dan persepsi responden mengenai biaya transportasi sesuai standar dengan menggunakan skala Likert menghasilkan nilai 456. Jadi untuk pertanyaan ini berada pada kategori sangat baik.

Maka berdasarkan hasil penelitian dapat disimpulkan bahwa menurut persepsi masyarakat Kota Padang Sumatera Barat telah siap menjadi destinasi wisata yang banyak mengandung unsur religi. Padang yang terkenal dengan budaya dengan berlandas Adat Bansandi Syarak, Syarak Bansandi Kitabullah tidaklah mengherankan apabila Padang dijuluki kota religi atau destinasi wisata syariah. Secara prinsip itu, dari segi implementasinya di Kota Padang sesuai dengan visi misi pariwisata yang dilandasi dengan budaya dan religius tahap 2014-2019 ini, maka dari itu religius merupakan bagian yang akan mewarnai dari pariwisata yang dikerahkan di Padang.

\section{Kesimpulan dan Saran}

\section{Kesimpuan}

Berdasarkan hasil penelitian yang telah dikemukakan maka dapat diambil kesimpulan sebagai berikut : 
1. Persepsi masyarakat Kota Pekanbaru tentang kesiapan Pekanbaru menjadi destinasi wisata syariah dinyatakan baik dan siap oleh responden. Hal ini bisa dilihat dari aspek daya tarik wisata dan infrastruktur wisatanya.

2. Persepsi masyarakat Kota Padang tentang kesiapan Padang menjadi destinasi wisata syariah dinyatakan baik dan siap oleh responden. Hal ini juga dilihat dari aspek daya tarik wisata dan infrastruktur wisatanya.

\section{Saran}

Adapun saran-saran yang dapat dikemukakan sehubungan dengan penelitian ini adalah:

1. Diharapkan kepada pemerintah untuk dapat melakukan sosialisasi mengenai konsep dan tujuan pengembangan wisata syariah kepada masyarakat dan pelaku industri pariwisata di Pekanbaru dan Padang.

2. Meningkatkan komitmen pemerintah daerah dalam mengembangkan wisata syariah misalnya dalam hal insentif keringanan biaya dan proses kepada pelaku usaha yang menggunakan sertifikat halal.

3. Diharapkan kepada seluruh stakeholder agar dapat mengoptimalkan sarana ibadah yang layak disemua daya tarik wisata.

\section{DAFTAR PUSTAKA}

Bungin, Burhan, 2004. Metodologi Penelitian Sosial, Surabaya: Airlangga University Press.

Hamzah, Maulana.Mdan Yudiana, Yudi. 2015. Analisis Komparatif Potensi Industri Halal dalam Wisata Syariah dengan Konvensional

Global Muslim Travel Index (GMTI). 2016. 
Kempar.2015. Jumlah Kunjungan Wisatawan Mancanegara Menurut Pintu Masuk dan Kebangsaan.Jakarta: Kementerian Pariwisata.

Kotler, Philip, dan Kevin L. Keller. 2009. Manajemen Pemasaran jilid1.AlihBahasa: Benyamin Molan. EdisiKetigaBelas. AlihBahasa : Bob Sabran. Jakarta: Erlangga.

Kotler, Philip, dan Kevin L. Keller. 2009. Manajemen Pemasaran jilid2.AlihBahasa: Benyamin Molan. EdisiKetigaBelas. AlihBahasa : Bob Sabran. Jakarta: Erlangga. Kuncoro, Mudjarad, 2007, Metode Kuantitatif Teori dan Aplikasi untuk Bisnis dan Ekonomi. Yogjakarta : IPD STIM YKPN.

Moleong, Lexy.J, 2005, Metodologi Penelitian Kualitatif, Bandung : Remaja Rosdakarya. Narbuko, Chalil, Abu Achmadi, 2004, Metodologi Penelitian, Jakarta :Penerbit Bumi Askara.

Sarwono, J. 2009. Statistik Itu Mudah. Yogyakarta: CV Andi Offset.

Setiadi. 2005. Perilaku Konsumen: Konsep dan Implikasi UntukStrategi dan Penelitian Pemasaran.

Sofyan, Riyanto. 2012. Prospek Bisnis Pariwisata Syariah. Jakarta: Republika.

Sugiyono, 2005.Metode Penelitian Bisnis, Bandung : Alfabeta

Suharso, Puguh, 2010. Model Analisis Kuantitatif. Jakarta : Indeks. 